\title{
Three distinct regions of deletion on 13q in squamous cell carcinoma of the larynx
}

\author{
AGNIESZKA STEMBALSKA $^{1}$, NIKOLAUS BLIN ${ }^{2}$, DAVID RAMSEY $^{3}$ and MARIA M. SASIADEK ${ }^{1}$ \\ ${ }^{1}$ Department of Genetics, Wroclaw Medical University, Marcinkowskiego 1, Wroclaw 50-368, Poland; ${ }^{2}$ Division of \\ Molecular Genetics, University of Tuebingen, Institute of Human Genetics, Wilhelmstr. 27, D-72074 Tuebingen, \\ Germany; ${ }^{3}$ Institute of Mathematics, Technical University, Wybrzeze Wyspianskiego 27, Wroclaw, Poland
}

Received December 19, 2005; Accepted March 13, 2006

\begin{abstract}
Genetic etiology of squamous cell carcinoma of the larynx (SCCL) is very complex, with both molecular and chromosomal alterations involved. The target genes have not yet been clearly identified. Therefore, our study focused on searching for regions that potentially harbor genes related to SCCL. After comparative genomic hybridization (CGH) analysis of a set of 52 SCCL we specified 13q21-q32 and $13 q 34$ as the most frequently deleted regions. In order to precisely map the critical region of deletion, we studied these areas by using 15 microsatellite markers. In our material a significantly high frequency of loss of heterozygosity (LOH) (test for a difference in two proportions, $\mathrm{p}<0.001$ ) was observed for the following markers: D13S1320 (13q21.1), D13S800 (13q21.3), D13S1818 (13q32.1), D13S770 (13q32.3) and D13S285 (13q34). Three hot spots of $\mathrm{LOH}$ were found: 13q21.1-q22.1 (D13S1320-D13S1824-D13S800-SHGC30014WI-16413-D13S1186), 13q.31.1-13q32.3 (D13S317D13S1818-D13S770), 13q34 (D13S285). Among these areas, 13q31.1-q32.3 was identified as new hot spot of deletion in SCCLs.
\end{abstract}

\section{Introduction}

Intensive studies on the genetic etiology of HNSCC (head and neck squamous cell carcinoma) have shown that the etiology of HNSSC is very complex, with both molecular and chromosomal alterations involved (1). Chromosomal analyses, employing classic and molecular techniques, revealed the presence of a variety of balanced and imbalanced chromosomal aberrations in HNSCC cells. The karyotypes were shown to be complex with the breakpoints underlying chromosomal alterations located mainly at 1p, 1q, 3p, 3q, 4q, 8p, 8q, 9p, 10p,

Correspondence to: Professor Maria Sasiadek, Department of Genetics, Wroclaw Medical University, Marcinkowskiego 1, 50-368 Wroclaw, Poland

E-mail: sasiadek@gen.am.wroc.pl

Key words: chromosome 13q, laryngeal cancer, comparative genomic hybridization, loss of heterozygosity
$10 \mathrm{q}, 11 \mathrm{q}, 13 \mathrm{q}, 14 \mathrm{q}$ and $15 \mathrm{q}$. Among the recurrent structural chromosomal aberrations, isochromosomes $8 \mathrm{q}$, deletion at $3 p$, and homogeneously staining regions at $11 q 13$ were most often observed (2-4). The chromosomal model of HNSCC development and progression indicates two common genetic pathways: one with $-1 \mathrm{p},-1 \mathrm{q}$ and $-7 \mathrm{q}$ as early events, followed by $-8 p$ and $-4 p$, and another one starting with $+7 q$, and subsequently followed by $+11 \mathrm{pq},+8 \mathrm{q}$ and $+1 \mathrm{pq}$. Both pathways then converge to a common set of imbalances: $-3 p,-9 p$ and $-11 q(5)$.

Comparative genomic hybridization enabled the identification of chromosomal imbalances. Gains were observed mainly in $3 q$ and $8 q$, while losses occurred in $3 p, 13 q$ and $22 q$ $(6,7)$. Huang et al proposed that $+3 q /-3 p$ are the most important chromosomal events in the genetic etiology of HNSCC, which then may be followed by additional chromosomal imbalances, occurring with various frequencies depending on the tumor location (pharyngeal, laryngeal and oral squamous cell carcinoma) (8). The molecular data also revealed an involvement in the etiology of HNSCC of a variety of genes, such as oncogenes, e.g. MYC, RAS, ERBB2, BCL2, and tumor suppressor genes (TSG), e.g. TP53, RB (9-13). A sequence of frequent allelic loss observed at 9p, 3p, 17q, 4q, 13q followed by $\mathrm{LOH}$ at $18 \mathrm{q}$ and $8 \mathrm{p}$ has been suggested as a critical pathway for HNSCC development and progression (14).

However, the target genetic alterations for carcinogenesis of HNSCC have not yet been precisely specified. Therefore, our study focused on searching for the regions which potentially harbor genes critical in squamous cell carcinoma of the larynx (SCCL), which is the most frequently observed cancer among HNSCCs.

\section{Materials and methods}

We studied a homogeneous set of 52 primary squamous cell carcinoma of the larynx (70.6\% transglottic SCCL-s). Cancer tissues and matched blood samples were obtained from the Department of Otolaryngology, Wroclaw Medical University, Poland. Biological material for molecular analysis was collected before chemotherapy and/or radiotherapy. DNA was isolated from cancer tissue (the tumor specimens frozen) and the corresponding peripheral blood lymphocytes using standard techniques. To minimize the possible bias resulting from the contamination of tested samples by the normal tissue, 


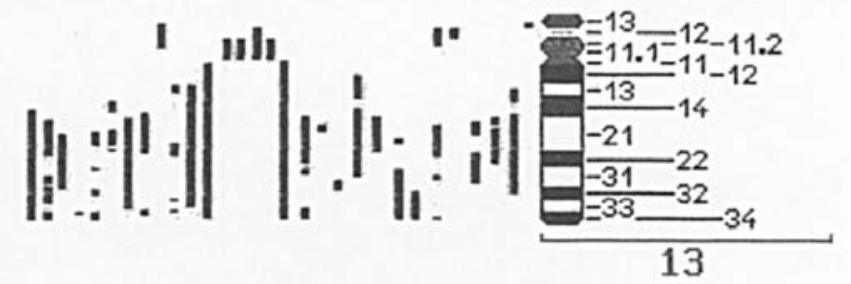

Figure 1. Chromosome losses on 13q detected by CGH, in the set of 52 squamous cell carcinoma of larynx. a dissection of tumor was performed to remove non-tumor tissue. In all of the samples tested more than $70 \%$ of the cells were cancer cells. The program of the study was accepted by the University Ethics Committee. None of the patients had a history of hereditary cancer.

To search for the regions which potentially harbor genes critical in SSCL, CGH and LOH were applied. In the first step CGH was performed on 52 tumors. Seventeen tumors were found to carry the 13q21-q32 (Fig. 1), 13q34 deletions ( $p<0.01$,

Table I. Results of LOH analyses in two set of squamous cell carcinoma of larynx, one presented with (cases 1-17) and the other without (cases 17-34) a deletion 13q21-q34 observed in CGH.

\begin{tabular}{|c|c|c|c|c|c|c|c|c|c|c|c|c|c|c|c|c|}
\hline $\begin{array}{l}\text { No. } \\
\text { (bp) }\end{array}$ & $\begin{array}{c}\text { Deletions } \\
\text { 13q21-q32, } \\
\text { 13q34 in CGH }\end{array}$ & $\begin{array}{c}\text { D13 } \\
\text { S1320 } \\
13 \mathrm{q} 21.1 \\
224-268\end{array}$ & $\begin{array}{c}\text { D13 } \\
\text { S1824 } \\
13 \mathrm{q} 21.1 \\
164-188\end{array}$ & $\begin{array}{c}\mathrm{D} 13 \\
\text { S800 } \\
13 \mathrm{q} 21.3 \\
295-319\end{array}$ & $\begin{array}{c}\text { SHGC } \\
30014 \\
13 q 22.1 \\
100\end{array}$ & $\begin{array}{c}\text { WI- } \\
19625 \\
13 q 22.1 \\
257\end{array}$ & $\begin{array}{c}\text { WI- } \\
16413 \\
13 \mathrm{q} 22.1 \\
132\end{array}$ & $\begin{array}{c}\mathrm{D} 13 \\
\text { S755 } \\
13 \mathrm{q} 22.1 \\
205\end{array}$ & $\begin{array}{c}\text { D13 } \\
\text { S1186 } \\
13 \mathrm{q} 22.1 \\
151\end{array}$ & $\begin{array}{c}\text { WI- } \\
17550 \\
13 \mathrm{q} 22.1 \\
150\end{array}$ & $\begin{array}{c}\text { D13 } \\
\text { S317 } \\
13 \mathrm{q} 31.1 \\
175-199\end{array}$ & $\begin{array}{c}\text { D13 } \\
\text { S1818 } \\
13 \mathrm{q} 32.1 \\
239-255\end{array}$ & $\begin{array}{c}\text { D13 } \\
\text { S770 } \\
13 \mathrm{q} 32.3 \\
234-258\end{array}$ & $\begin{array}{c}\text { D13 } \\
\text { S1820 } \\
13 q 33.3 \\
187-202\end{array}$ & $\begin{array}{c}\text { D13 } \\
\text { S1315 } \\
13 q 34 \\
162-180\end{array}$ & $\begin{array}{c}\text { D13 } \\
\text { S285 } \\
13 q 34 \\
113\end{array}$ \\
\hline 1 & + & $\mathrm{LOH}$ & $\mathrm{LOH}$ & Het & $\mathrm{LOH}$ & $\mathrm{H}$ & Het & $\mathrm{H}$ & $\mathrm{LOH}$ & Het & $\mathrm{LOH}$ & $\mathrm{LOH}$ & $\mathrm{LOH}$ & Het & Het & $\mathrm{LOH}$ \\
\hline 2 & + & LOH & Het & Het & LOH & $\mathrm{H}$ & Het & $\mathrm{H}$ & $\mathrm{N}$ & $\mathrm{H}$ & Het & LOH & LOH & Het & Het & Het \\
\hline 3 & + & Het & $\mathrm{H}$ & LOH & Het & $\mathrm{H}$ & Het & $\mathrm{H}$ & $\mathrm{N}$ & Het & LOH & LOH & LOH & Het & $\mathrm{H}$ & $\mathrm{LOH}$ \\
\hline 4 & + & LOH & LOH & LOH & Het & $\mathrm{H}$ & Het & $\mathrm{H}$ & LOH & $\mathrm{H}$ & Het & LOH & Het & Het & LOH & $\mathrm{LOH}$ \\
\hline 5 & + & LOH & Het & LOH & $\mathrm{N}$ & $\mathrm{H}$ & $\mathrm{H}$ & $\mathrm{H}$ & $\mathrm{N}$ & Het & LOH & LOH & Het & Het & Het & Het \\
\hline 6 & + & $\mathrm{H}$ & Het & Het & Het & $\mathrm{H}$ & Het & $\mathrm{H}$ & LOH & Het & Het & Het & $\mathrm{H}$ & Het & Het & Het \\
\hline 7 & + & Het & Het & Het & Het & $\mathrm{H}$ & Het & $\mathrm{H}$ & Het & Het & Het & Het & Het & Het & Het & Het \\
\hline 8 & + & Het & Het & Het & Het & $\mathrm{H}$ & $\mathrm{H}$ & LOH & LOH & Het & Het & Het & Het & Het & Het & Het \\
\hline 9 & + & LOH & LOH & Het & Het & $\mathrm{H}$ & LOH & $\mathrm{H}$ & LOH & Het & LOH & Het & Het & Het & LOH & $\mathrm{LOH}$ \\
\hline 10 & + & Het & LOH & LOH & Het & $\mathrm{H}$ & Het & $\mathrm{H}$ & LOH & Het & LOH & LOH & LOH & LOH & Het & Het \\
\hline 11 & + & LOH & LOH & Het & LOH & $\mathrm{H}$ & Het & $\mathrm{H}$ & Het & Het & LOH & LOH & LOH & LOH & $\mathrm{H}$ & $\mathrm{LOH}$ \\
\hline 12 & + & LOH & $\mathrm{H}$ & LOH & Het & $\mathrm{H}$ & Het & $\mathrm{H}$ & LOH & Het & Het & LOH & LOH & LOH & $\mathrm{H}$ & $\mathrm{LOH}$ \\
\hline 13 & + & Het & Het & LOH & Het & $\mathrm{H}$ & Het & $\mathrm{H}$ & Het & Het & Het & Het & LOH & Het & $\mathrm{H}$ & $\mathrm{LOH}$ \\
\hline 14 & + & LOH & LOH & LOH & LOH & $\mathrm{H}$ & LOH & $\mathrm{H}$ & LOH & Het & LOH & LOH & LOH & LOH & $\mathrm{H}$ & Het \\
\hline 15 & + & Het & $\mathrm{H}$ & Het & LOH & $\mathrm{H}$ & Het & Het & Het & Het & Het & Het & LOH & Het & Het & Het \\
\hline 16 & + & LOH & Het & LOH & LOH & $\mathrm{H}$ & Het & $\mathrm{H}$ & LOH & Het & LOH & LOH & LOH & Het & LOH & Het \\
\hline 17 & + & $\mathrm{LOH}$ & $\mathrm{LOH}$ & LOH & LOH & $\mathrm{H}$ & Het & $\mathrm{H}$ & Het & Het & Het & $\mathrm{LOH}$ & $\mathrm{LOH}$ & Het & Het & Het \\
\hline 18 & - & LOH & LOH & LOH & $\mathrm{H}$ & $\mathrm{LOH}$ & $\mathrm{N}$ & $\mathrm{H}$ & Het & $\mathrm{H}$ & $\mathrm{H}$ & Het & $\mathrm{N}$ & LOH & $\mathrm{H}$ & $\mathrm{H}$ \\
\hline 19 & - & Het & Het & Het & $\mathrm{H}$ & $\mathrm{H}$ & LOH & $\mathrm{H}$ & $\mathrm{N}$ & $\mathrm{H}$ & $\mathrm{H}$ & $\mathrm{H}$ & LOH & Het & Het & $\mathrm{H}$ \\
\hline 20 & - & LOH & $\mathrm{H}$ & LOH & $\mathrm{H}$ & Het & LOH & $\mathrm{H}$ & Het & $\mathrm{H}$ & Het & Het & Het & $\mathrm{H}$ & LOH & $\mathrm{H}$ \\
\hline 21 & - & Het & Het & Het & $\mathrm{N}$ & $\mathrm{H}$ & LOH & $\mathrm{H}$ & $\mathrm{N}$ & $\mathrm{N}$ & Het & Het & $\mathrm{N}$ & Het & Het & $\mathrm{H}$ \\
\hline 22 & - & $\mathrm{H}$ & Het & LOH & Het & Het & $\mathrm{N}$ & $\mathrm{H}$ & Het & Het & $\mathrm{H}$ & Het & Het & LOH & $\mathrm{H}$ & $\mathrm{H}$ \\
\hline 23 & - & $\mathrm{H}$ & $\mathrm{H}$ & $\mathrm{N}$ & $\mathrm{N}$ & Het & $\mathrm{N}$ & $\mathrm{H}$ & Het & Het & $\mathrm{H}$ & $\mathrm{H}$ & Het & Het & $\mathrm{H}$ & $\mathrm{H}$ \\
\hline 24 & - & Het & Het & $\mathrm{H}$ & $\mathrm{LOH}$ & $\mathrm{H}$ & $\mathrm{N}$ & $\mathrm{H}$ & Het & $\mathrm{N}$ & Het & Het & Het & Het & Het & $\mathrm{H}$ \\
\hline 25 & - & $\mathrm{H}$ & Het & LOH & LOH & $\mathrm{H}$ & LOH & $\mathrm{H}$ & Het & $\mathrm{N}$ & $\mathrm{LOH}$ & $\mathrm{LOH}$ & LOH & Het & $\mathrm{H}$ & $\mathrm{LOH}$ \\
\hline 26 & - & Het & Het & Het & $\mathrm{H}$ & Het & $\mathrm{N}$ & $\mathrm{H}$ & Het & $\mathrm{N}$ & Het & $\mathrm{LOH}$ & Het & Het & Het & $\mathrm{LOH}$ \\
\hline 27 & - & Het & LOH & $\mathrm{LOH}$ & $\mathrm{LOH}$ & $\mathrm{H}$ & $\mathrm{N}$ & $\mathrm{H}$ & Het & Het & $\mathrm{LOH}$ & Het & Het & $\mathrm{LOH}$ & Het & $\mathrm{LOH}$ \\
\hline 28 & - & $\mathrm{H}$ & LOH & LOH & Het & $\mathrm{H}$ & $\mathrm{N}$ & $\mathrm{H}$ & Het & Het & LOH & LOH & LOH & $\mathrm{H}$ & LOH & $\mathrm{LOH}$ \\
\hline 29 & - & Het & Het & Het & LOH & $\mathrm{H}$ & H & Het & LOH & Het & Het & Het & Het & Het & Het & Het \\
\hline 30 & - & LOH & LOH & $\mathrm{H}$ & Het & $\mathrm{H}$ & LOH & $\mathrm{H}$ & Het & LOH & LOH & LOH & Het & $\mathrm{H}$ & LOH & $\mathrm{H}$ \\
\hline 31 & - & $\mathrm{N}$ & Het & Het & Het & $\mathrm{H}$ & LOH & $\mathrm{H}$ & Het & Het & Het & Het & Het & $\mathrm{H}$ & Het & $\mathrm{H}$ \\
\hline 32 & - & Het & Het & Het & Het & $\mathrm{H}$ & LOH & $\mathrm{H}$ & Het & Het & Het & Het & LOH & Het & $\mathrm{H}$ & Het \\
\hline 33 & - & $\mathrm{H}$ & Het & LOH & Het & Het & $\mathrm{N}$ & $\mathrm{H}$ & Het & LOH & $\mathrm{H}$ & LOH & $\mathrm{N}$ & Het & LOH & $\mathrm{LOH}$ \\
\hline 34 & - & Het & Het & Het & Het & LOH & LOH & $\mathrm{H}$ & $\mathrm{H}$ & Het & Het & Het & Het & $\mathrm{H}$ & Het & Het \\
\hline
\end{tabular}




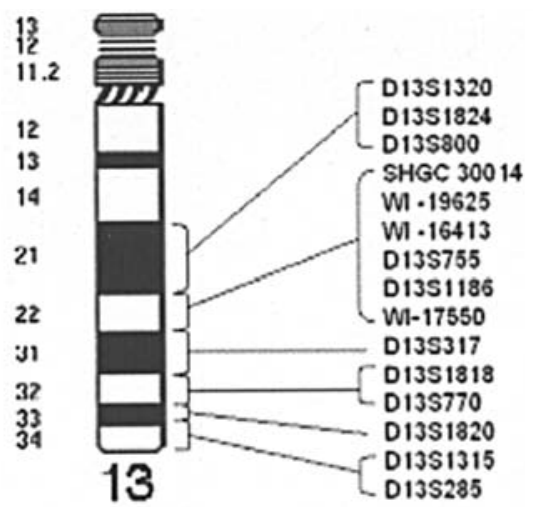

Figure 2. Localization of 15 microsatellite markers used in our study to determine $\mathrm{LOH}$ on $13 \mathrm{q}$, in the set of 34 squamous cell carcinoma of the larynx.

test for the difference of two proportions). Therefore, LOH analysis was performed on two sets of matched tumors: 17 carrying and 17 not carrying this deletion (Table I). The LOH analyses were repeated 3 times and the results were reproducible.

CGH analysis. CGH was performed according to standard procedures (15). Briefly, human male reference DNA was labeled with rhodamine-5-dUTP (R-5-dUTP, Roche) and tumor DNA was labeled with fluorescein-12-dUTP (F-12-dUTP, Roche) using DOP-PCR. Fluorescein- and rhodaminelabeled DNA were precipitated together and hybridized to normal male $(46, \mathrm{XY})$ metaphase slides (Metaphase CGH Targed Slides; Vysis $\mathrm{GmbH}$ ). After the hybridization, the chromosomes were counterstained with DAPI in a Vectashield solution (Vector). Image acquisition and evaluation were done using a Leica DM-RB epifluorescence microscope equipped with Kappa CF 8/1 DX camera controlled by ISIS software (MetaSystems $\mathrm{GmbH}$ ). Three color images, green for tumor DNA, red for reference DNA and blue for DAPI counterstained were acquired from 10 to 20 metaphases per sample. The threshold values for detection of genomic imbalances were $<0.8$ for losses and $>1.25$ for gains.

LOH analysis. To determine minimal region of deletion, an analysis of loss of heterozygosity (LOH) using 15 microsatellite markers was applied (Fig. 2). The markers cover the 13q21-34 area suspected of being critical to SCCL. When screening band $13 \mathrm{q} 21$, the following markers were employed: D13S1320 (position $6160 \mathrm{kbp}$ ), D13S1824 (6505 kbp), D13S800 (7167 kbp), for band 13q22 the six following markers were applied: SHGC 30014 (7397 kbp), WI-19625 (7423 kbp), WI-16413 (7423 kbp), D13S755 (7496 kbp), D13S1186 (WI-YACMap position 187, ref. int. $\mathrm{WC}_{13.3}$ ) and WI-17550 (7525 kbp). Four markers were used for the analysis of bands 13q31.1-13q33.3: D13S317 (8052 kbp), D13S1818 (8739 kbp), D13S770 (9732 kbp) and D13S1820 (Marshfield Map position $90.27 \mathrm{cM}$ ), while the telomeric region (band 13q34) was analysed using two markers: D13S1315 (10804 kbp) and D13S285 (11074 kbp) (Table I). PCR was performed according to standard protocols in a PTC-200 thermocycler (MJ Research) on DNA isolated from SCCL, as well as from matched constitutional DNAs. Fluorescent PCR products were pooled and resolved on a $4 \%$ polyacrylamide gel supplemented with $7 \mathrm{M}$ urea in an ABI-377 sequencing device. The size and quantity of fluorescent PCR products were evaluated semiautomatically by Genescan and Genotyper software using an ABI-377 sequencer (Applied Biosystems). Allelic loss was defined as more than a $70 \%$ reduction in the area of the tumor peak compared to the peak area of the corresponding normal tissue (16). In LOH analysis only informative cases (heterozygotes) were taken into account.

Statistical analysis. The frequency of $\mathrm{LOH}$ for markers located on $13 q$ was analyzed. As it is accepted that $\mathrm{LOH}$ is associated with a cancer when the frequency of LOH is above $20 \%$ of analyzed cases, the test for difference in proportions was used to see whether any frequency was significant by greater than $20 \%(17-20) \cdot \chi^{2}$ test for independence, the Mann-Whitney test and Fisher's exact test for independence were used to analyze associations between the group of the tumors with deletion in region $13 \mathrm{q}$ in $\mathrm{CGH}$ and the group of the tumors without deletion in this region. All the calculations were carried out using the Statistica package.

\section{Results}

CGH analysis. In the original set of 52 LSCC 1961 chromosomal imbalances were detected. The frequency of chromosomal losses was 1042 and the frequency of gains was 919. The distribution of imbalances appeared to be non-random. In our material the highest frequency of losses was observed in chromosomal regions 13q21-q32 and 13q34 (test for a difference in two proportions compared to the overall level on all chromosomes, $\mathrm{p}<0.01)$.

LOH analysis. DNA from matched pairs of tumor and normal tissues of 34 patients were analyzed for LOH using 15 microsatellite markers. PCR was successfully performed for all markers with $>67 \%$ of informative allelotypes for 13 markers ( 2 markers non-informative). By using informative markers, the frequency of $\mathrm{LOH}$ (number of cases with $\mathrm{LOH} /$ number of informative cases) was established as ranging from 8 to $54.6 \%$ $(39.3 \pm 12.8 \%$; mean $\pm \mathrm{SD})$. In our material a significantly high frequency of $\mathrm{LOH}$ (test for a difference in two proportions, $\mathrm{p}<0.001)$ was observed for following markers: D13S1320 (13q21.1), D13S800 (13q21.3), D13S1818 (13q32.1), D13S770 (13q32.3) and D13S285 (13q34). All these markers showed $\mathrm{LOH}$ frequency higher than $48 \%$. A lower frequency of $\mathrm{LOH}$ (ranging from 38 to $43.5 \%$ ), however, still significant $(\mathrm{p}<0.01)$, was detected for markers: D13S1824 (13q21.1), SHGC30014 (13q22.1), WI-16413 (13q22.1) and D13S317 (13q31.1). In the tumors bearing the deletion visible in $\mathrm{CGH}$ the overall frequency of $\mathrm{LOH}$ was higher than in the tumors not carrying this deletion (35.2 and $25.1 \%$ respectively; $\mathrm{p}<0,05)$. However, both sets of tumors presented similar pattern of $\mathrm{LOH}$ distribution.

The hot spots of LOH were defined as regions showing frequent $\mathrm{LOH}$ but retaining heterozygosity for the flanking microsatellite. Three such regions were found: 13q21.1-q22.1 (D13S1320-D13S1824-D13S800-SHGC30014-WI-16413D13S1186), 13q.31.1-q32.3 (D13S317-D13S1818-D13S770), 
$13 q 34$ (D13S285). Among these areas, 13q31.1-q32.3 was identified as a new hot spot in SCCLs.

\section{Discussion}

Our study focused on searching for regions which potentially harbor genes critical in squamous cell carcinoma of the larynx (SCCL). CGH analysis allowed us to specify two critical chromosomal regions 13q21-13q32 and 13q34 as likely targets of deletion. Our data revealing the involvement of $13 \mathrm{q}$ in SCCL are in good agreement with the observations of Califano et al and Huang et al, who suggested that in the HNSCC progression an inactivation of at least one and possibly several tumor suppressor genes on $13 q$ are involved $(8,14,21)$. The contribution of $13 q$ to neoplastic transformation of a variety of tumors such as esophageal, head and neck, breast, ovarian and fallopian tube cancers has also been observed by many authors $(13,19,20)$. Comparing the results of CGH analysis of tumors with and without the deletion, the pattern of $\mathrm{LOH}$ distribution is similar for both groups. Therefore, it can be concluded that the minimal critical region of deletion on $13 \mathrm{q}$ in HNSCC may not be resolved by the classic CGH approach.

Thus, to determine the hot spots of deletion within the critical regions we applied $\mathrm{LOH}$ analysis using 15 microsatellite markers (positioned at distance of 400-800 kbp). This analysis confirmed and refined the presence of 3 distinct regions of deletions (hot spots): 13q21.1-q22.1, 13q.31.1-q32.3 and $13 \mathrm{q} 34$. High frequency of LOH in 13q14 ( $R B$ locus) was also observed in our material, as published elsewhere (22).

In our study 13q21.1-q22.1 was determined as a hot spot of deletion. CGH studies also revealed the involvement of this region in SCCL (23). Somatic deletion of 13q21-q22 was frequently observed in a diversity of tumors and therefore, the presence in this region of genes critical in cancerogenesis has been postulated by many authors. Up to now, key suppressor gene $B R C A 2$ (13q21), as well as other genes important in carcinogenesis such as protocadherin 9 (13q21-2), KLF12 and KLF5 (members of the mammalian Kruppel-like transcription factor family) were mapped to $13 q$ (20,24-30). LOH in $K L F 5$ was observed in sporadic breast cancer, furthermore in malignant fibrous histiocytoma (MFH) and in prostate cancer (28-32).

The CKAP2 gene (coding for the cytoskeleton-associated protein 2), which is probably important in the etiology of a variety of tumors, has been located in the region between the bands $13 \mathrm{q} 14.3 / 13 \mathrm{q} 22$, while the gene $H G M W$ (coding for the sciellin, a precursor to the cornified envelope of terminally differentiated keratinocytes) was found in 13q22 (33-35).

Both additional critical regions (13q.31.1-q32.3 and 13q34) were reported as frequently altered in primary nasopharyngeal carcinoma, prostate cancer and also in carcinoma hepatocellulare, HNSCC (36-41). About 20 genes were localized to $13 q 31-q 32$, some of them remaining poorly characterized. One of the most important genes located in $13 \mathrm{q} 34$ is INGI which is involved in the control of cell division and apoptosis (42). Mutations in INGl were found in HNSCC (43).

Concluding, ours is the first report revealing the involvement of 13q31.1-q32.3 in SCCL. Taking into account the biological functions of genes located within the delineated region, three genes are likely to be important for HNSCC development: glypican 5 (8974-9049kbp) and glypican 6 (9157-9275 kbp), that are involved in the control of cell growth and division (13q32) and claudin 10 (9378-9392 kbp) which is an integral membrane protein and a component of tight junction strands (44-47). Further studies are necessary to verify these assumptions.

\section{Acknowledgements}

The authors would like to thank Professor Tomasz Krecicki from the Department and Clinic of Otolaryngology, Medical University of Wroclaw, Poland for providing biological material. The project was supported by a grant from DAAD/ KBN 323-bis.

\section{References}

1. Fan CY: Genetic alterations in head and neck cancer: interactions among environmental carcinogens, cell cycle control and host DNA repair. Curr Oncol Rep 1: 66-71, 2001.

2. Jin YS, Higashi K, Mandahl N, Heim S, et al: Frequent rearrangement of chromosomal bands 1 p22 and 11q13 in squamous cell carcinomas of the head and neck. Genes Chromosomes Cancer 2: 198-204, 1990.

3. Van Dyke DL, Worsham MJ, Benninger MS, et al: Recurrent cytogenetic abnormalities in squamous cell carcinomas of the head and neck region. Genes Chromosomes Cancer 9: 192-206, 1994.

4. Soder AI, Hopman AH, Ramaekers FC, Conradt C and Bosch FX: Distinct non-random patterns of chromosomal aberrations in the progression of squamous cell carcinomas of the head and neck. Cancer Res 55: 5030-5037, 1995.

5. Hoglund M, Gisselsson D, Mandahl N, Johansson B, Mertens F, Mitelman F and Sall T: Multivariate analyses of genomic imbalances in solid tumours reveal distinct and converging pathways of karyotypic evolution. Genes Chromosomes Cancer 31: 156-171, 2001.

6. Bergamo NA, Rogatto SR, Poli-Frederico RC, Reis PP, Kowalski LP, Zielenska M and Squire JA: Comparative genomic hybridization analysis detects frequent over-representation of DNA sequences at $3 \mathrm{q}, 7 \mathrm{p}$ and $8 \mathrm{q}$ in head and neck carcinomas. Cancer Genet Cytogenet 119: 48-55, 2000.

7. Kujawski M, Sarlomo-Rikala M, Gabriel A, Szyfter K and Knuutila S: Recurrent DNA copy number losses associated with metastasis of larynx carcinoma. Genes Chromosomes Cancer 26: 253-257, 1999.

8. Huang Q, Yu GP, McCormick SA, et al: Genetic differences detected by comparative genomic hybridization in head and neck squamous cell carcinomas from different tumour sites: construction of oncogenetic trees for tumour progression. Genes Chromosomes Cancer 34: 224-233, 2002.

9. Voravud N, Charuruks N and Mutirangura A: Squamous cell carcinoma of head and neck. J Med Assoc Thai 80: 207-218, 1997.

10. Porter MJ, Field JK, Leung SF, Lo D, Lee JC, Spandidos DA and van Hasselt CA: The detection of the c-myc and ras oncogenes in nasopharyngeal carcinoma by immunohistochemistry. Acta Otolaryngol 114: 105-109, 1994.

11. Nguyen DC, Parsa B, Close A, Magnusson B, Crowe DL and Sinha UK: Overexpression of cell cycle regulatory proteins correlates with advanced tumour stage in head and neck squamous cell carcinomas. Int J Oncol 22: 1285-1290, 2003.

12. Muller D, Millon R, Velten M, et al: Amplification of 11q13 DNA markers in head and neck squamous cell carcinomas: correlation with clinical outcome. Eur J Cancer 33: 2203-2210, 1997.

13. Fracchiolla NS, Pruneri G, Pignataro L, et al: Molecular and immunohistochemical analysis of the bcl-1/cyclin D1 gene in laryngeal squamous cell carcinomas: correlation of protein expression with lymph node metastases and advanced clinical stage. Cancer 79: 1114-1121, 1997.

14. Califano J, van der Riet $\mathrm{P}$, Westra W, et al: Genetic progression model for head and neck cancer: implications for field cancerization. Cancer Res 56: 2488-2492, 1996. 
15. Kallioniemi OP, Kallioniemi A, Piper J, Isola J, Waldman FM, Gray JW and Pinkel D: Optimizing comparative genomic hybridization for analysis of DNA sequence number changes in solid tumours. Genes Chromosomes Cancer 10: 231-243, 1994

16. Karnik P, Paris M, Williams BR, Casey G, Crowe J and Chen P: Two distinct tumour suppressor loci within chromosome 11p15 implicated in breast cancer progression and metastasis. Hum Mol Genet 7: 895-903, 1998.

17. Ah-See KW, Cooke TG, Pickford IR, Soutar D and Balmain A: An allelotype of squamous carcinoma of the head and neck using microsatellite markers. Cancer Res 54: 1617-1621, 1994.

18. Nawroz H, van der Riet P, Hruban RH, Koch W, Ruppert JM and Sidransky D: Allelotype of head and neck squamous cell carcinoma. Cancer Res 54: 1152-1155, 1994.

19. Canzian F, Salovaara R, Hemminki A, Kristo P, Chadwick RB, Aaltonen LA and De la Chapelle A: Semi-automated assessment of loss of heterozygosity and replication error in tumours. Cancer Res 56: 3331-3337, 1996.

20. Jongsma AP, Piek JM, Zweemer RP, et al: Molecular evidence for putative tumour suppressor genes on chromosome 13q specific to BRCA1 related ovarian and fallopian tube cancer. Mol Pathol 55: 305-309, 2002.

21. Califano J, Westra WH, Koch W, et al: Unknown primary head and neck squamous cell carcinoma: molecular identification of the site of origin. J Natl Cancer 91: 599-604, 1999.

22. Krecicki T, Smigiel R, Fraczek M, Kowalczyk M and Sasiadek MM: Studies of the cell cycle regulatory proteins P16, cyclin D1 and retinoblastoma protein in laryngeal carcinoma tissue. J Laryngol Otol 118: 676-680, 2004.

23. Kujawski M, Rydzanicz M, Sarlomo-Rikala M, Gabriel A and Szyfter K: Chromosome alterations reflect clonal evolution in squamous cell carcinoma of the larynx. Med Sci Monit 8: BR279-BR282, 2002.

24. Szukala K, Brieger J, Bruch K, Biczysko W, Wierzbicka M, Szyfter W and Szyfter K: Loss of heterozygosity on chromosome arm 13q In larynx cancer patients: analysis of tumour, margin and clinically unchanged mucosa. Med Sci Monit 10: CR233-CR240, 2004.

25. Kainu T, Juo SH, Desper R, et al: Somatic deletions in hereditary breast cancers implicate $13 \mathrm{q} 21$ as a putative novel breast cancer susceptibility locus. Proc Natl Acad Sci USA 97: 9603-9608, 2000.

26. Rozenblum E, Vahteristo P, Sandberg T, et al: A genomic map of a 6-Mb region at 13q21-22 implicated in cancer development: identification and characterization of candidate genes. Hum Genet 110: 111-121, 2002

27. Turner J and Crossley M: Mammalian Kruppel-like transcription factors: more than just a pretty finger. Trends Biochem Sci 24: 236-240, 2000.

28. Chen C, Brabham WW, Stults BG, et al: Defining a common region of deletion at 13q21 in human cancers. Genes Chromosomes Cancer 3: 333-344, 2001.

29. Chen C, Bhalala HV, Vessella RL and Dong JT: KLF5 is frequently deleted and down-regulated but rarely mutated in prostate cancer. Prostate 55: 81-88, 2003.

30. Larramendy ML, Lushnikova T, Bjorkqvist A, et al: Comparative genomic hybridization reveals complex genetic changes in primary breast cancer tumors and their cell lines. Cancer Genet Cytogenet 119: 132-138, 2000

31. Marial A, Terrier P, Chibon F, Sastre X, Lecesne A and Aurias A: Loss of chromosome 13 is the most frequent genomic imbalance in malignant fibrous histiocytomas. Cancer Genet Cytogenet 111: 134-138, 1999.
32. Dong JT, Chen C, Stultz BG, Isaacs JT and Frierson HF Jr: Deletion at $13 \mathrm{q} 21$ is associated with agressive prostate cancers. Cancer Res 60: 3880-3883, 2000.

33. Rakhmanaliev ER, Klimov EA, Kompaniitsev AA and Sulimova GE: The structure of the human oncogenesisassociated CKAP2 (LB1) gene. Mol Biol 36: 985-989, 2002.

34. Champliaud MF, Burgeson RE, Jin W, Baden HP and Olson PF: cDNA cloning and characterization of sciellin, a LIM domain protein of the keratinocyte cornified envelope. J Biol Chem 273: 31547-31554, 1998.

35. Champliaud MF, Baden HP, Koch M, Jin W, Burgeson RE and Viel A: Gene characterization of sciellin (SCEL) and protein localization in vertebrate epithelia displaying barrier properties. Genomics 70: 264-268, 2000.

36. Tsang Y, Lo K, Leung S, Choi P, Fong Y, Lee J and Huand D: Two distinct regions of deletion on chromosome $13 q$ in primary nasopharyngeal carcinoma. Int J Cancer 83: 305-308, 1999.

37. Hyytinen E, Frierson HF Jr, Boyd JC, Chung LWK and Dong JT: Three distinct regions of allelic loss at 13q14, 13q21-22 and 13q33 in prostate cancer. Genes Chromosomes Cancer 25: 108-114, 1999.

38. Lin Y-W, Sheu J-C, Liu L-Y, et al: Loss of heterozygosity at chromosome 13q in hepatocellular carcinoma: identification of three independent regions. Eur J Cancer 35: 1730-1734, 1999.

39. Nagai H, Pineau P, Tiollais P, Buendia MA and Dejean A: Comprehensive allelotyping of human hepatocellular carcinoma. Oncogene 14: 2927-2933, 1997.

40. Maestro R, Piccinin S, Doglioni C, et al: Chromosome 13q deletion mapping in head and neck squamous cell carcinomas: identification of two distinct regions of preferential loss. Cancer Res 56: 1146-1150, 1996.

41. Gupta VK, Schmidt AP, Pashia ME, Sunwoo JB and Scholnick SB: Multiple regions of deletion on chromosome arm $13 q$ in head-and-neck squamous-cell carcinoma. Int J Cancer 84: 453-457, 1999.

42. Helbing C, Veillette C, Riabowol K, Johnston R and Garkavtsev I: A novel candidate tumor suppressor, IHG1, is involved in the regulation of apoptosis. Cancer Res 57: 1255-1258, 1997.

43. Gunduz M, Ouchida M, Fukushima K, Hanafusa H, Etani T, Nishoka $\mathrm{S}$ and Shimizu K: Genomic structure of the human ING1 gene and tumor-specific mutations detected in head and neck squamous cell carcinomas. Cancer Res 60: 3143-3146, 2000.

44. $\mathrm{Yu} \mathrm{W}$, Inoue J, Imoto I, Matsuo Y, Karpas A and Inazawa J: GPC5 is a possible target for the 13q31-q32 amplification detected in lymphoma cell lines. J Hum Genet 48: 331-335, 2003.

45. Veugelers M, De Cat B, Ceulemans H, et al: Glypican-6, a new member of the glypican family of cell surface heparan sulfate proteoglycans. J Biol Chem 274: 26968-26977, 1999.

46. Kitajiri SI, Furuse M, Morita K, Saishin-Kiuchi Y, Kido H, Ito J and Tsukita S: Expression patterns of claudins, tight junction adhesion molecules, in the inner ear. Hear Res 187: 25-34, 2004.

47. Hoshizuma A, Ueno T, Furuse M, Tsukita S, Nakanishi Y and Hieda Y: Expression patterns of claudin family of tight junction membrane proteins in developing mouse submandibular gland. Dev Dyn 231: 425-431, 2004. 